\title{
Environmental Life Cycle Assessment for a Large- Scale Gold Mining
}

\author{
María José González-Campo, M.Sc.1, Jorgelina Pasqualino, P.hD.1, Claudia Díaz-Mendoza, M.Sc.1, and Alfonso \\ Rodríguez-Dono, P.hD.2 \\ 1Universidad Tecnológica de Bolívar, Colombia, mgonzalez@utb.edu.co,jpasqualino@utb.edu.co,cdiaz@utb.edu.co \\ 2Universitat Politècnica de Catalunya, Spain, alfonso.rodriguez@upc.edu
}

\begin{abstract}
Mining, generally speaking, is an industry which consumes water in an intensive way, and when metal fineness is less and more mineral is extracted, the consumption of this important source will also increase.

In the last 40 years alone, global production trends of the mineral extractive, manufacturing and services industries have grown steadily. In Peru, for example, it has reduced the total area of glaciers and fresh water in the coasts, where around $60 \%$ of the population lives.

For reasons like the one above, it is becoming more and more necessary to identify and assess the impacts that this sector generates in order to be able to propose solutions at least for the most significant ones.

In this article, using the life cycle assessment (LCA) software SimaPro, an assessment focused on large scale gold mining by heap leaching has been made, identifying that the processes that have the worst effects on the environment resulted to be processing, mainly, and leaching in second place. Moreover, the most affected impact categories were: climate change, agricultural land occupation, water and metal depletion.

On the other hand, another three different impact categories, terrestrial, freshwater and marine ecotoxicity, showed an inverse result which could be translated as a potential positive impact, however due to the inventory and data collected, the affirmation cannot be possible to sustain.
\end{abstract}

\section{INTRODUCTION}

Many countries around the world have mining as one of their main engines of economic development, but this activity is also one of the sectors that generates the most environmental and social problems. A fact of special relevance, given the non-renewable nature of these minerals and the extractive activities necessary to obtain them, efforts should be made to ensure that their management is as sustainable as possible and in accordance with local, regional and global commitments regarding environmental conservation.

The extraction of gold, specifically, and the processes that this implies, have caused important adverse effects on the environment and human health; both in its small and largescale commissioning. Great dispositions of mercury have generated great damages to ecosystems and people, even death itself. So, looking for intervention measures (either in terms of prevention, mitigation and / or compensation) to the negative environmental impacts generated in this activity, it is necessary to perform, as well as the identification and quantification of the impacts in each related process, in order to make timely and appropriate decisions to the needs of the environment and global.
Hence the importance of the implementation of the Life Cycle Assessment methodology, because through a detailed study of the phases that make up the life of a product, from its obtaining from nature to its subsequent disposition and return to it; provides timely information on the environmental aspects that relate to it, thus helping to have a clear idea of how sustainable this product is, identify the processes or inputs that have the greatest impact and be able to effectively manage them.

Applying this methodology in gold mining would mean having detailed knowledge of the processes that comprise it, its inputs and outputs, pollutants, co-products or by-products; of the procedures to strengthen or improve; and, in short, to be able to act in a timely manner in the face of the environmental and social problems it faces.

\section{A. Processing routes}

Mining in general is a type of industry that deals with ore extraction from its deposits, which are then transformed for manufacture of the required product according to the kind of mining performed. Ore can be found on surface and disaggregated or as an integer part of a rock either underground or open pit.

Its exploiting method is chosen as a function of morphologic characteristics from the mineralized bodies and its relation with the surface [38].

There are four mining phases that would be stablished as characteristic of today's activities: Prospection, exploration, development and exploitation. Finally, after the rock where the ore is located is exploited, it is then transferred to treatment plants that specialized on separating the precious metal on the ore. On this stage there is a physical preparation and then a metallurgic process begin as such [26]. For the particular case studied on this article, extracting method implemented was pile lixiviation, which requires perforation and blowing up of the rocky surface of the earth, loading and transport of the ore to the lixiviation piles. These piles and pools are ready to contain and capture gold in solution on the lixiviation process. Lixiviate is then refined on multiple stages transforming it into Doré bars completes all the stages of processing performed on the mine [24].

Water surplus from the processing stage and the acid dripping from the piles are treated before they can be sent to the water treatment plants. To prevent system degradation sediment control structures are used. Once an area is inactive, it is filled with rock leftovers, cover with a layer of dirt or 
protecting layers in some cases, and modified during its recovery [24].

\section{METHODS}

In accordance to [2], in Figure 1, the structure followed in the methodology is presented as the Life Cycle Assessment Framework.

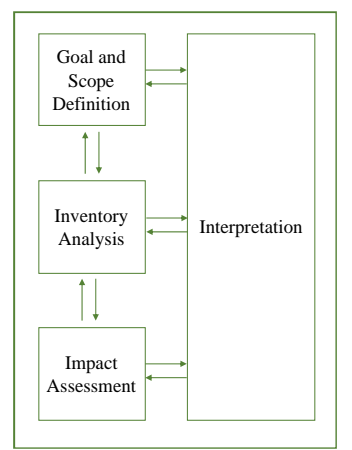

Figure 1. Fig. 1 Life Cycle Assessment Framework. Source: [2]

\section{A. Goal and Scope Definition}

The Scope of this research is based on the gate-to-gate method, which it is related to the production phase of the gold mining life cycle, and includes excavation and extraction, leaching and processing phases. Excluding administrative and informative services or other type of support activities or related to them.

This study is based on the total production of $2.17 \mathrm{E}+08 \mathrm{~g}$ doré, which includes $9.43 \mathrm{E}+07 \mathrm{~g}$ gold and $1.23 \mathrm{E}+08 \mathrm{~g}$ silver. Likewise, mercury, as a co-product is considered, with a production amount of $5.99 \mathrm{E}+07 \mathrm{~g}$.

The goal is to define the baseline through the environmental impact's identification of a large-scale gold mine, in order to stablish potential intervention measures. Hence, an environmental life cycle assessment for a largescale gold mine has been conducted.

Besides the above, the study is based on previous research made by [24].

\section{B. System boundaries}

The System Boundaries as Figure 2 shows, which highlights the three major phases to assess are excavation and extraction, Leaching and Processing. In the background the activities necessary for its implementation. The timeframe assessed is one year.

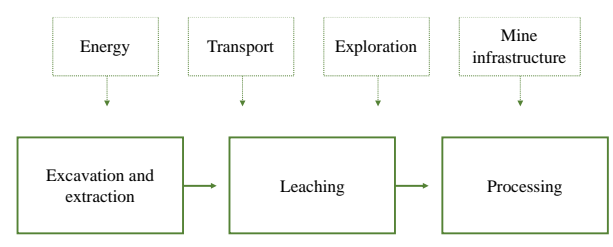

Figure 2. System Boundaries.

Background processes are given in. The phase to analyze is the production.

\section{Impact Assessment and Methods}

Life Cycle Assessment is an environmental management tool, which iteratively and methodologically provides a systematic framework that serves as a support in the comprehensive assessment of the environmental impacts of a system under study. The integration of each of the phases of Figure 1 with all the others that involve the framework, is relevant, because through it, getting results that simulate the reality of it, as close as possible, will be achievable.

According to [2], and as shown in Figure 3, the indicator of an impact category can be chosen anywhere along the impact pathway, which links inventory data to impacts on the Area of Protection (AoP) [3]. Hence, the chosen AoP level assessed were midpoint categories: Climate Change, Terrestrial acidification, Human toxicity, Photochemical oxidant formation, Particulate matter formation, Terrestrial ecotoxicity, Natural land transformation, Water depletion, Metal depletion (ReCiPe Hierarchist) (v.1.1, 2014).

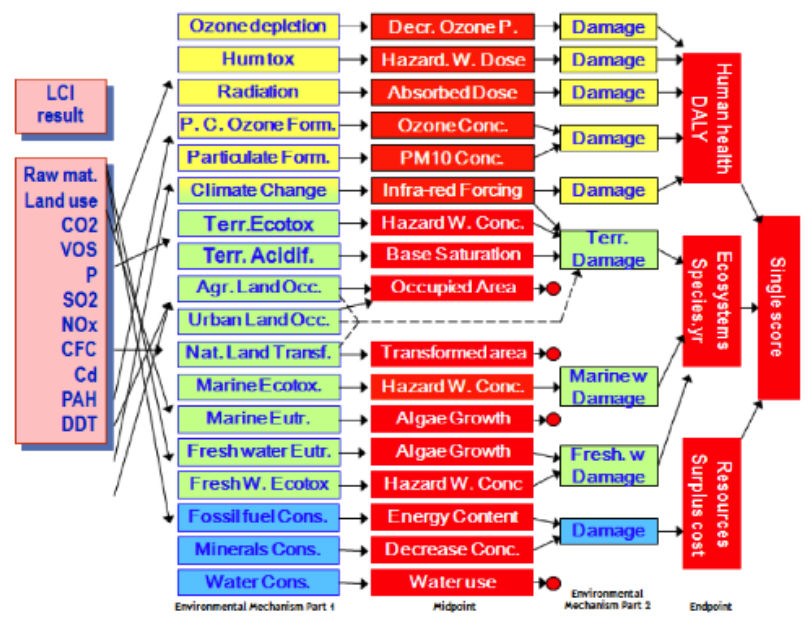

Figure 3. Overall scheme Midpoint and Endpoint impact categories. Source: SimaPro Database Manual Methods Library. PRé, various authors. Report versión 2.8. April 2015.

Simapro is the LCA software chosen for this case which helps gather, analyze and monitor sustainability performance of goods and services.

This software allows to analyze and model complex life cycles in a systemic and transparent way, to measure environmental impact of goods and services through all stages of the life cycle and to identify access points in all aspects of supply chain; thus, timely actions may be taken to positively impact a product life cycle [4].

\section{Assumptions}

Functional unit: $2.17 \mathrm{E}+08 \mathrm{~g}$ Doré, which includes $9.43 \mathrm{E}+07 \mathrm{~g}$ gold and $1.23 \mathrm{E}+08 \mathrm{~g}$ silver.

Considered processes: Excavation and extraction, leaching and processing Mining type: Open-pit miming. 
Gold is main metal product, and mercury as by-product from gold recovery.

By-product: 5,99E+07g Mercury.

\section{E. Inventory Tables}

Present project is based on a study made by [24]. Which centers on an open pit mine in Peru, which generates Doré as a product, which is a mix of gold $(43,38 \%)$ and silver $(56,62 \%)$ as well as mercury as a byproduct.

Table 1. Process input inventory.

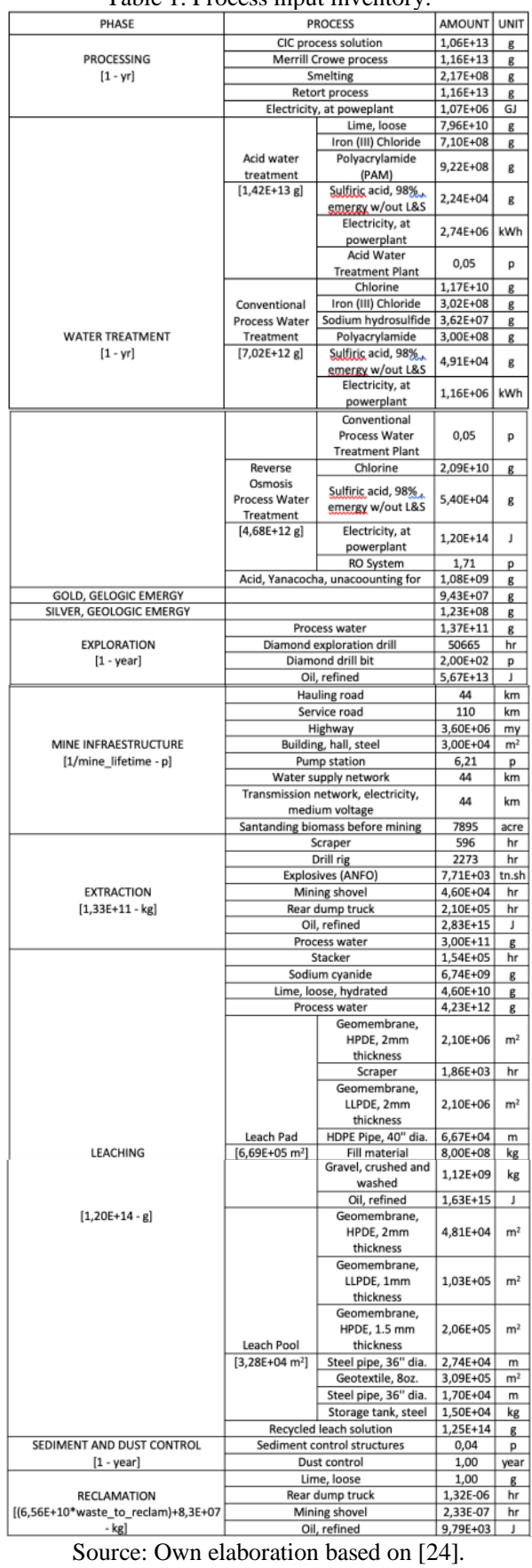

Table 2. Process output inventory

\begin{tabular}{|c|c|c|c|}
\hline PHASE & PROCESS & AMOUNT & UNIT \\
\hline PROCESSING & & 1,00 & yr \\
\hline \multirow{3}{*}{$\begin{array}{l}\text { WATER TREATMENT } \\
{[1-\mathrm{yr}]}\end{array}$} & Acid Water Treatment & $1,42 \mathrm{E}+13$ & $\mathrm{~g}$ \\
\hline & Conventional Process Water Treatment & $3,1 \mathrm{E}+12$ & $\mathrm{~g}$ \\
\hline & $\begin{array}{l}\text { Reverse Osmosis Process Water } \\
\text { Treatment }\end{array}$ & $5,55 \mathrm{E}+12$ & g \\
\hline EXPLORATION & & 1,00 & $\mathrm{yr}$ \\
\hline MINE INFRAESTRUCTURE & & 1,00 & $p$ \\
\hline EXTRACTION & & $1,99 \mathrm{E}+11$ & $\mathrm{~kg}$ \\
\hline \multirow{2}{*}{$\begin{array}{c}\text { LEACHING } \\
{[1,21 \mathrm{E}+14-\mathrm{g} \text { leachate }]}\end{array}$} & Leach Pad & $2,10 E+06$ & $\mathrm{~m}^{2}$ \\
\hline & Leach Pool & $1,03 E+05$ & $\mathrm{~m}^{2}$ \\
\hline $\begin{array}{l}\text { SEDIMENT AND DUST } \\
\text { CONTROL }\end{array}$ & & 1,00 & yr \\
\hline RECLAMATION & & 1,00 & kg \\
\hline
\end{tabular}

Source: Own elaboration based on [24].

\section{RESULTS AND DISCUSSION}

Figure 4 shows results obtained from the process characterization through factors representing its contribution to a specific impact category in relationship with the gold activity of the mine. This way values are obtained with equivalent units and may be added to measure each process contribution for a specific impact category. This equivalent units are total emissions converted to each category, to refer to that emission quantity and, according to the analysis method, each one determines its referent contaminants.

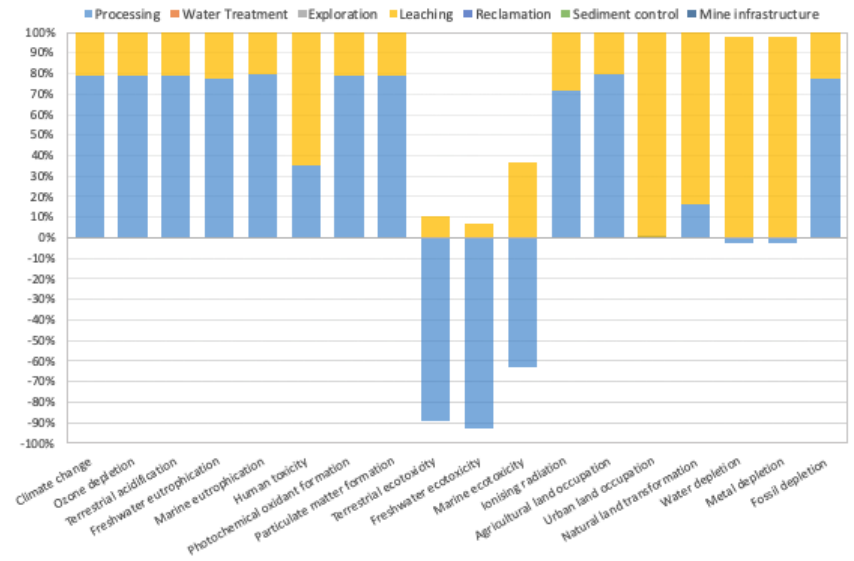

Figure 4. Environmental impact assessment of 2,17E+08g of Doré, by impact category. Characterization. Analysis method: World ReCiPe Midpoint (H).

Thus, it is observed that phases with the higher impacts are lixiviation and ore processing, on yellow and blue colors respectively. Likewise, it may be observed that for each impact category negative effects are reflected, but only one phase of the life cycle shows a positive impact on one of them, which is evidenced on the behavior of the positive bars (negative impact) and negative (positive impact). This is the case of ore processing compared to the other phases on the following impact categories:

- $\quad$ Terrestrial ecotoxicity $\approx 89,3 \%$

- $\quad$ Freshwater ecotoxicity $\approx 92,9 \%$

- Marine ecotoxicity $\approx 63,0 \%$

- Water depletion $\approx 2,2 \%$

- Metal depletion $\approx 2,2 \%$ 
In order to analyze why this is happening, process that compose this phase of the life cycle are detailed and may be observed on Table 3:

Table 3. Ore processing and its subprocesses.

\begin{tabular}{|c|c|}
\hline Phase & Process \\
\hline & Carbon in column \\
\hline Processing & Merrill Crowe \\
& Fundition \\
\hline
\end{tabular}

These are the processes from where ore is in the enriched solution from the piles or lixiviation pads, until metal casting to obtain Doré bars. On first instance, it may be considered that, since processes are for the metal solution treatment, software counts them as a positive impact on the previous impact categories. However, it is also observed on Figure 5, that after the enriched solution is obtained coming from the lixiviation pad, a closed circuit is generated until the Merrill Crowe process, due to the remaining solution, also called Barre, is then reused and reincorporated to the lixiviation pad after consumed cyanide on the carbon in column (CIC) and Merrill Crowe process is added.

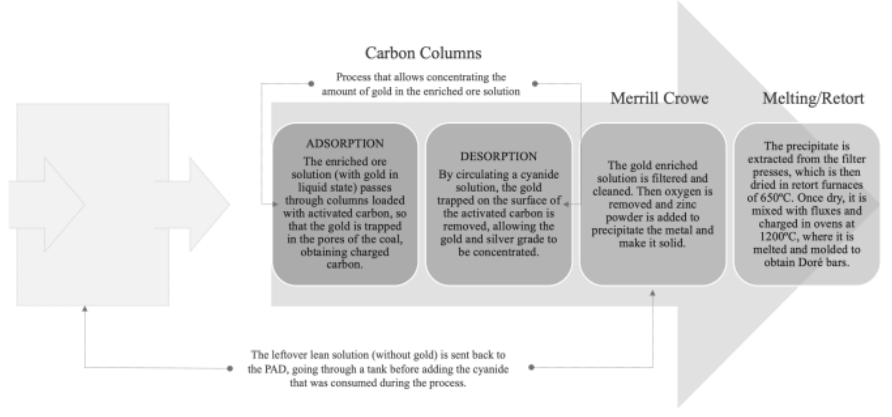

Figure 5. Subprocesses in processing phase. Source: [26]

However, it may not be stated that a positive impact is present on these categories mainly because there is no generated product that benefits the environment on these aspects. But as it is being compared with other phases with negative impact, then it is taken as such. It should be noted as a process that is not generating any kind of affectation thus its impact is null.

Data was then normalized in such a way that the phase or category that results on an effect, either positive or negative, major or minor, can be appreciated. Thus, Figure 6 has been obtained, which aligned with Figure 4, showing that, among all life cycle phases, processing and lixiviation (without accounting for negative values) are the ones with the biggest impacts.

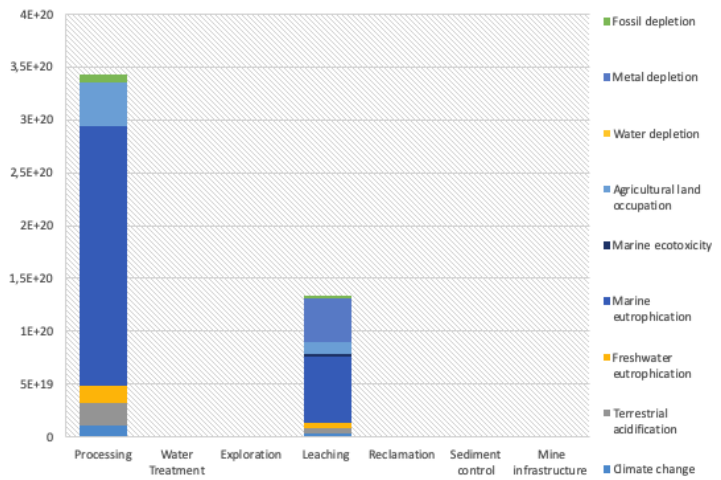

Figure 6. Inventory normalization of impact categories based on the study case life cycle.

Next, with only those phases and with the normalized data, as is shown in Figure 7, it can be clearly seen the magnitude of impact that generates on each category, where processing is the one that generates the most adverse impacts, except for metal depletion where it is outweighed by lixiviation.

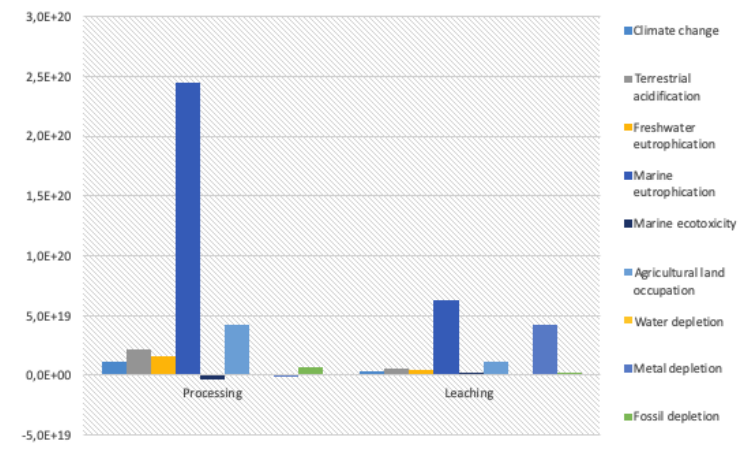

Figure 7. Inventory normalization, based on processing and lixiviation phases.

Mining, on a general sense, is an industry that consumes water on an intensive way and when the lower the metal (law) and the more extracted ore there is, the more water will be demanded [9][10].

Just in the last 40 years there has been a steady growth of the world production of extractive ore industries, manufacturing and services [9]; and from 2005 to 2012 gold yearly production has increased $1 \%$ [10]. Hence this means that water consumption has risen as well and its adverse effects too.

In Peru, for example, from 1969 to 2004 there has been a reduction of a $22 \%$ of the total glacial area and a $12 \%$ of fresh water on coastal areas (where 60\% of population lives) and is being estimated a loss of water close to $7.000 \mathrm{Mm}_{3}$ [11-13].

Therefore, and even though the mining study project it is not responsible for it, results provided regarding climate change impact are not consequent. 


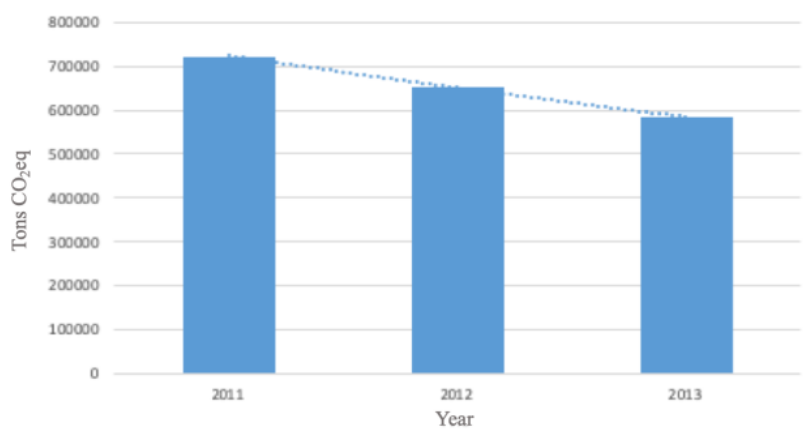

Figure 8. Research's mine total emissions in TonCO2eq. Source: Own elaboration based on [16].

Figure 8 shows calculation of Carbon Footprint from the mine operation between 2011 and 2013; where on 2012 and 2013 reductions of $9 \%$ and $11 \%$ were obtained. This proves that in spite of the negative effects that the mine operative process is generating, there has been a reduction over time.

Meanwhile data from emissions of 1994, 2000 and 2010, from the Integrated National Inventory of Greenhouse Gas Emissions of Peru on 2010 and the (Peru's First Biennial Update Report to the United Nations Framework Convention on Climate Change), on a national level perspective, are different for the ore industry where emissions has been increasing over time as it is shown on Table 4 and Figure 9:

Table 4. Greenhouse Gases Emissions in 1994, 2000 and 2010.

\begin{tabular}{cccc}
\hline & \multicolumn{3}{c}{ Emisiones GEI [GgCO $\mathbf{~}_{2}$ eq] } \\
\hline Fuente de GEI & 1994 & 2000 & 2010 \\
Minería & 842 & 1356 & 1673,94 \\
\hline
\end{tabular}

Source: Peru's First Biennial Update Report to the United Nations Framework Convention on Climate Change.

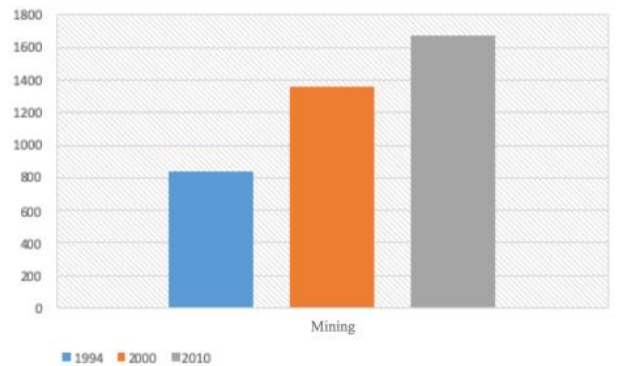

Figure 9. Greenhouse Gases Emissions in GgCO2eq. Source: Peru's First Biennial Update Report to the United Nations Framework Convention on Climate Change.

The following are projections from Greenhouse Gas emissions for the country up to the year 2050 according to [27] on year 2000:

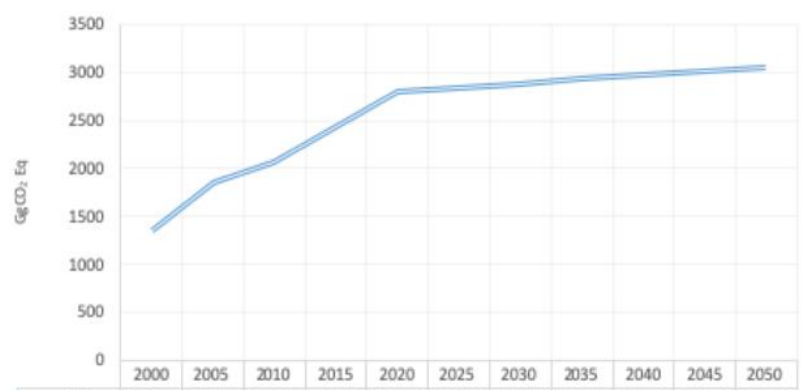

$=$ Mining 1356,17 1844,23 2068,58 2434,432800,29 2843,29 2886,28 2929,272972,27 $3015,263058,26$

Figure 10. Greenhouse Gases Emissions Projection, from 2000 to 2050. Source: [27].

Where it is observed that from 2025 to 2050 values won't change on hundreds of $\mathrm{GgCO} 2 \mathrm{eq}$ as in the years before that, but they will remain around $43 \mathrm{GgCO} 2$ eq. However, for this trend to remain constant it is imperative that activities such as mining, which not only relates ore processing to these emissions but also to land transformation and use that goes with it, to stay low under established parameters by Environmental Legislation and International Agreements.

\section{CONCLUSIONS}

From the Life Cycle Assessment performed, it may be concluded that processes that generate larger negative impacts are: (a) processing, which reflects higher negative impact in terms of Climate Change and Agricultural Land Occupation; and (b) lixiviation, which has higher relevancy around Water and Metal Depletion. As it is shown in Table 5, Figure 4 and Figure 7.

Table 5. Main life cycle phases that generates adverse effects and categories with highest impact.

\begin{tabular}{|c|c|c|c|}
\hline Impact category & Unit & Processing & Lixiviation \\
\hline Climate change & $\mathrm{kg} \mathrm{CO}_{2}$ eq & $7,5 \mathrm{E}+22$ & \\
\hline $\begin{array}{c}\text { Agricultural land } \\
\text { occupation }\end{array}$ & $\mathrm{m}^{2} \mathrm{a}$ & $2,3 \mathrm{E}+23$ & \\
\hline Water depletion & $\mathrm{m}^{3}$ & & $1,3 \mathrm{E}+22$ \\
\hline Metal depletion & $\mathrm{kg} \mathrm{Fe}$ eq & & $1,9 \mathrm{E}+22$ \\
\hline
\end{tabular}

Although there have been positive effects of the processing phase in the terrestrial, marine and fresh water ecotoxicity categories, this could not be affirmed since there is no generated product that benefits the environment in these aspects. However, since it is being compared with other phases that are having a negative impact on these categories, it is considered as such. It would be argued, rather, that it is not generating any type of affection in this regard, so its impact would be nil. 


\section{ACKNOWLEDGMENT}

The authors would like to thank Universitat Politècnica de Catalunya and Universidad Tecnológica de Bolívar, throughout this research was made and developed, also to GISAH research group for their support. Finally, but not less important, to [24] for his entirely support.

\section{REFERENCES}

[1] Adams, M. D., 2005. Advances in Gold Ore Processing. Perth, Western Australia: B. A. Wills.

[2] Environmental management - Life cycle assessment - Principles and framework. 14040:2006.

[3] European Commission - Joint Research Centre - Institute for Environment and Sustainability, 2010. International Reference Life Cycle Data System (ILCD) Handbook - Specific Guide for Life Cycle Inventory Data Sets. EUR 24709 EN. Luxembourg: Publications Office of the European Union.

[4] SimaPro. 2020. About Simapro - Simapro. [online] Available at: <https://simapro.com/about/>.

[5] Asociación Española de Normalización y certificación, AENOR., 2008. Análisis de Ciclo de Vida. Madrid: AENOR.

[6] Burt, R., 1984. Gravity Concentration Technology. Elsevier Science Publishers.

[7] Intergovernmental Panel on Climate Change, 2014. Climate Change 2014 Mitigation of Climate Change. Fifth Assessment Report.

[8] Kelly, T. and Matos, G., 2013. Mineral Resources Program. [online] Usgs.gov. Available at: <https://www.usgs.gov/energy-andminerals/mineral-resources-program $>$.

[9] Intergovernmental Panel on Climate Change, 2007. 2007: Freshwater Resources and Their Management. Climate Change 2007: Impacts, Adaptation and Vulnerability. Contribution of Working Group II to The Fourth Assessment Report of The Intergovernmental Panel on Climate Change. Cambridge, UK.

[10] Hinsdale, J., 2020. Vanishing Glaciers: The Future of Water in Peru's High Andes. [online] State of the Planet. Available at: $<$ https://blogs.ei.columbia.edu/2018/06/12/vanishing-glaciers-futurewater-perus-high-andes/>

[11] Mark, B. and Seltzer, G., 2003. Tropical glacier meltwater contribution to stream discharge: a case study in the Cordillera Blanca, Peru. Journal of Glaciology, 49(165), pp.271-281.

[12] Engineering Laboratory-NIST., 2009. BEES. Available at: <http://www.nist.gov/el/economics/BEESSoftware.cfm>

[13]Reporte de sostenibilidad 2013. 2014. [online] Available at: <http://www.yanacocha.com/wp-content/uploads/2010/04/2013-Reportede-sostenibilidad-Yanacocha.pdf $>$.

[14]Gold and Gold Mining., 2007. In G. F. Nordberg, B. A. Fowler, \& M. Nordberg, Handbook on the Toxicology of Metals (p. 1542). Elsevier B.V.

[15]Güereca, L. P., Gassó, S., Baldasano, J. M., \& Jiménez Guerrero, P., 2006

[16]U.S. Environmental Protection Agency; Scientific Applications International Corporation., 2006. Life Cycle Assessment: Principles and Practice. Cincinnati, Ohio: Office of Research and Development - EPA.

[17]United Nations Environment Program., n.d.. Newsletter and Technical Publications. Available at: Freshwater Management Series No. 2: <http://www.unep.or.jp/Ietc/Publications/Freshwater/FMS2/index.asp>

[18] Life Cycle Assessment of Two Bio-waste Management Systems for Barcelona, Spain. Resources, Conservation and Recycling, 17.

[19]Hartman, H. L., 1996. SME Mining Engineering Handbook. United States of America: Society for Mining, Metallurgy, and Exploration, Inc.

[20]Heijungs, R., Guinee, J. B., Huppes, G., Lankreijer, R. M., Udo De Haes, H. A., Wegener Sleeswijk, A., . . De Goede, H. P., 1992. Environmental Life Cycle Assessment of Products: Guide and Backgrounds. Leiden: CML Leiden.

[21]IIED - International Institute for Environment and Development., 2003. MMSD - Mining, Minerals and Sustainable Development Project.
[22]Wong Wai, L. E., \& Mujumdar, A. S., 2009. Gold Extraction and Recovery Processes. Singapore: Minerals, Metals and Materials Technology Center (M3TC) - NUS.

[23]PRé Consultants., 2015. SimaPro | World's Leading LCA Software. Available at: 〈http://www.pre-sustainability.com/simapro>

[24]Ingwesen, W. W., 2011. Emergy as a Life Cycle Impact Assessment Indicator A Gold Mining Case Study. US Environmental Protection Agency Papers, 37.

[25]Institute of Environmental Sciences (CML) Universiteit Leiden., 2009. CMLCA. Available at: <http://cml.leiden.edu/software/softwarecmlca.html>

[26]Jiménez, R., Díaz, X., De La Torre, E., Espí, J., Pantoja, F., \& Menéndez, M., 2001. Las Tecnologías específicas de la recuperación metalúrgica del oro. In El Libro de la Minería del Oro en Iberoamérica (p. 398). José Antonio Espí; RED XIII-B, CYTED; Comité Aurífero del Perú.

[27] Ministerio del Ambiente - MINAM, 2008. Estudio: Inventario Nacional Integrado De Emisiones De Gases De Efecto Invernadero Del Perú En El Año 2000. Lima, Perú.

[28]Kelly, E. y., 1999. Introducción al Procesamiento de Minerales. México: Limusa.

[29]Klapwijk, B., Marleen, R., Heijungs, R., \& Van Mourik, P., 2003. Levenscyclusanalyse Voor Onderzoekers, Ontwerpers en Beleidsmakers. Delft: DUP Blue Print.

[30]Maksaev, V., 2013. CEC - FCFM Universidad de Chile. Available at: <http://www.cec.uchile.cl/ vmaksaev/DEPOSITOS\%20DEL\%20TIPO\% 20SKARN.pdf>

[31]Marsden, J., \& House, I., 1992. The chemistry of the gold extraction. New York: Ellis Horwood.

[32]Ministerio de Energía y Minas del Perú., n.d.. Producción minera. Perú

[33]Ministerio de Energía y Minas. Reporte Anual 2013. 2014. Boletín Estadístico de Minería. Perú.

[34]Muhtadi, O. A., 1988. Chapter 8 - Metal Extraction (Recovery Systems) . In S. o. Inc., Introduction to Evaluation, Design and Operation of Precious Metal Heap Leaching Projects (p. 13). Littleton, Colorado: Dirk J.A. Van Zyl; Ian P. G. Hutchison; Jean E. Kiel.

[35]Mulder, K., 2007. Desarrollo Sostenible Para Ingenieros. Barcelona: EDiciones UPC.

[36]Newmont Mining Corporation., 2014. Delivering on our commitments.

[37]Oyarzun, R., Higueras, P., \& Lillo, J., 2011. Minería Ambiental: Una Introducción a los Impactos y su Remediación. España: Oyarzun, Roberto; Cubas, Paloma; GEMM.

[38] Romero Díaz De Ávila, M. T., 2010. Análisis del Ciclo de Vida (ACV) Herramienta de Gestión Ambiental. España: EOI.

[39]Sánchez-Palencia, F. J., Orejas, A., \& Fernández-Posse, M. D., 2001. La Península Ibérica, antigua tierra de riquezas. In El Libro de la Minería del Oro en Iberoamérica (p. 398). José Antonio Espí; Red XIII-B, CYTED; Comité Aurífero del Perú.

[40]Scott, S., \& Matchett, K., 2004. MINATAUR ${ }^{\mathrm{TM}}$ : the Mintek alternative technology to gold refining. The Journal of The South African Institute of Mining and Metallurgy, 6 .

[41]The International Journal of Life Cycle Assessment., 2015. Available at: $\langle$ http://www.springer.com/environment/journal/11367>

[42]U.S. Environmental Protection Agency., 2007. Treatment Technologies For Mercury in Soil, Waste and Water. Washington D.C. 